\title{
Antiproliferative Activity of Dibenzoylmethanes from Root Bark of Muellera filipes (Benth) M.J. Silva \& A.M.G. Azevedo
}

\author{
Érica L. Santos, ${ }^{a}$ Juliana Jo, ${ }^{a}$ Francisco A. Marques, ${ }^{a}$ Ana Maria G. A. Tozzi, ${ }^{b}$ \\ Ana Lúcia T. G. Ruiz and Beatriz Helena L. N. S. Maia*,a
}

${ }^{a}$ Departamento de Química, Universidade Federal do Paraná, Centro Politécnico, 81531-990 Curitiba-PR, Brazil

${ }^{b}$ Departamento de Biologia Vegetal, Instituto de Biologia, Universidade Estadual de Campinas, 13083-970 Campinas-SP, Brazil

${ }^{c}$ Divisão de Farmacologia e Toxicologia, Centro Pluridisciplinar de Pesquisas Químicas Biológicas e Agrícolas (CPQBA), Universidade Estadual de Campinas, 13148-218 Paulínia-SP, Brazil

\begin{abstract}
Three new dibenzoylmethane derivatives, $(E)-3,4$-methylenedioxy-2'-methoxy2",2"-dimethylpyrano-(5",6":3',4')-7-methoxychalcone, 2'-hydroxy-5' (3",",3","-dimethylallyl)8 -( $\alpha, \alpha$-dimethylallyl)-furano-(4",5":3'4')-dibenzoylmethane and 2'-O-(3",3"'-dimethylallyl)8 -( $\alpha, \alpha$-dimethylallyl)-furano-(4", 5"':3'4')-dibenzoylmethane, were isolated from a dichloromethane extract from the root bark of Muellera filipes (Benth.) M.J. Silva \& A.M.G. Azevedo, along with two dibenzoylmethane derivatives, 2 '-methoxy-8-( $\alpha, \alpha$-dimethylallyl)-furano$(4 ", 5 ": 3$ ',4')-dibenzoylmethane and 2'-hydroxy-8-( $\alpha, \alpha$-dimethylallyl)-2",2"-dimethylpyrano$\left(5^{\prime \prime}, 6\right.$ "':3',4')-dibenzoylmethane; one flavanone, isolonchocarpin and one flavone, pongaglabrone, which had been previously isolated from other sources. The molecular structures of the new dibenzoylmethane derivatives were determined by analysis of their spectral data $\left({ }^{1} \mathrm{H}\right.$ and ${ }^{13} \mathrm{C}$ nuclear magnetic resonance (NMR), 2D-NMR, NOE (nuclear Overhauser effect) and HRMS (high resolution mass spectrometry). The known compounds were identified using 1D experiments and comparison with spectral data from the literature. 2'-O-(3",3"'-Dimethylallyl)8 -( $\alpha, \alpha$-dimethylallyl)-furano-(4",5":3'4')-dibenzoylmethane displayed strong activity against the human cancer cell line OVCAR-3 (ovarian), and 2'-methoxy-8-( $\alpha, \alpha$-dimethylallyl)-furano$\left(4^{\prime}, 5^{\prime}: 3\right.$ ', 4')-dibenzoylmethane showed high selectivity for cell lines NCI-H460 (lung) and UACC-62 (melanoma).
\end{abstract}

Keywords: Muellera filipes, Fabaceae, flavonoids, dibenzoylmethanes, antiproliferative activity

\section{Introduction}

In continuation of our studies on flavonoids from the species of Lonchocarpus (Fabaceae) occurring in Brazil, we examined Lonchocarpus filipes Benth., which, based on molecular data and morphological analysis, was reclassified as Muellera filipes (Benth.) M.J. Silva \& A.M.G. Azevedo, together with Muellera montana A.M.G. Azevedo (previously Lonchocarpus montanus A.M.G. Azevedo). ${ }^{1,2}$ The genus Muellera L.f. has been treated as a synonym of Lonchocarpus Kunth (Fabaceae) and formerly included two species, M. moniliformis and M. fluvialis. Based on the new classification, this genus comprises 26 species, mainly in South America. ${ }^{2,3}$

*e-mail: noronha@ufpr.br
Phytochemical data obtained for Lonchocarpus and the allied genera Muellera and Dahlstedtia allowed the characterization of many secondary metabolites, mainly flavonoid structural types. ${ }^{4,5}$ Dibenzoylmethane is a $\beta$-diketone compound belonging to a small group of flavonoids that are rarely found in nature, but has been isolated from L. costaricensis, L. latifolius, D. floribunda (previously L. subglaucescens), D. muehlbergiana (previously L. muehlbergianus), D. glaziovii, M. fluvialis (previously L. fluvialis), M. montana and M. filipes. ${ }^{1,4,6-13}$ These compounds can potentially be used as biomarkers of these three genera. Dibenzoylmethane derivatives have attracted considerable attention because of their photoprotective properties. They prevent radiation from penetrating to vital cell components, and block overproduction of oxygen-derived free radicals, reducing 
skin damage from UV radiation in sunlight. ${ }^{14,15}$ Significant antitumor, antimalarial and trypanocidal activities have recently been reported for a number of dibenzoylmethanes and synthetic derivatives. ${ }^{16}$

We report here the isolation and characterization of three new dibenzoylmethane derivatives (1-3) together with four known compounds (4-7), from the root bark of $M$. filipes. The antiproliferative activity of the dibenzoylmethane derivatives was evaluated.

\section{Experimental}

\section{General experimental procedures}

1D and 2D nuclear magnetic resonance (NMR) data were recorded at $293 \mathrm{~K}$ in $\mathrm{CDCl}_{3}$ on a Brüker Avance DRX 400 operating at $9.4 \mathrm{~T}$, observing ${ }^{1} \mathrm{H}$ at $400.1 \mathrm{MHz}$ and ${ }^{13} \mathrm{C}$ at $100.6 \mathrm{MHz}$. Chemical shifts $(\delta)$ are given in ppm relative to TMS $(\delta 0.00)$ as the internal standard. High resolution mass spectra (HRMS) were recorded on a Bruker Daltonics MicroQTOF mass spectrometer equipped with an electrospray ionization (ESI) source and GC-MS (gas chromatography-mass spectrometry) data were acquired in a Shimadzu GC-17A chromatograph interfaced with a MS-QP5050A mass spectrometer. Optical rotations were measured in $\mathrm{CHCl}_{3}$ solutions at room temperature on a Jasco polarimeter model P-2000. The UV-Vis spectra were obtained in $\mathrm{CHCl}_{3}$ on a UV-2401PC (Shimadzu) spectrophotometer system. Column chromatography (CC) separations were on silica gel 60 (70-230 mesh, Merck). Thin layer chromatography (TLC) was pre-coated silica gel plates $\left(60 \mathrm{~F}_{254}\right.$ Merck, $0.25 \mathrm{~mm}$, aluminum) and precoated silica gel plates ( $60 \mathrm{PF}_{254}$ Merck, $1 \mathrm{~mm}$, glass) were used for preparative TLC. Compounds were detected by $\mathrm{UV}(\lambda=254$ and $366 \mathrm{~nm})$ irradiation and with solution of anisaldehyde, followed by heating.

\section{Plant material}

The roots of M. filipes were collected in the Ecological Park, State University of Campinas (UNICAMP, CampinasSP, Brazil) in September 2009. The plant was identified by Dr A. M. G. A. Tozzi from the Biology Institute of UNICAMP. A voucher specimen (A.M.G.A. Tozzi 143605) is deposited at the herbarium of UNICAMP.

\section{Extraction and isolation}

Dried and pulverized roots barks (137.1 g) of M. filipes were successively extracted with petroleum ether $\left(50-60^{\circ} \mathrm{C}\right)$, dichloromethane and methanol for $60 \mathrm{~h}$ in a Soxhlet apparatus. Removal of the solvents from the extracts under reduced pressure gave the petroleum ether extract as viscous yellow oil $(3.29 \mathrm{~g})$, while the dichloromethane $(5.27 \mathrm{~g})$ yield amorphous brown solid and the methanol extract (22.45 g) gave a brown gum. Part of the dichloromethane extract $(4.0 \mathrm{~g})$ was fractionated by silica gel CC $(0.063-0.200 \mathrm{~mm}$, $50.0 \times 4.0 \mathrm{~cm}$ ) eluted first with petroleum ether. The eluent polarity was gradually increased by addition of ethyl acetate and then methanol to furnish 201 fractions $(30 \mathrm{~mL}$ each) which were reduced to 32 groups after TLC analysis. Most of the compounds were found in four groups ranging from fractions 32 to 91 . A sample of each was further fractionated by successive preparative TLC (silica gel) respectively run with petroleum ether:ethyl acetate (25:75), petroleum ether:dichloromethane (20:80) and petroleum ether:dichloromethane (10:90). Flavonoids were visualized under UV light $(\lambda=254$ and $366 \mathrm{~nm})$ and recovered from TLC plates by extraction with dichloromethane to furnish dibenzoylmethanes derivatives $\mathbf{1}(8.5 \mathrm{mg}), \mathbf{2}(10.0 \mathrm{mg})$, $\mathbf{3}$ (53.4 mg), 4 (58.2 mg), 5 (8.3 mg), 6 (4.5 mg) and 7 (3.6 mg).

\section{Filipone A (1)}

Viscous yellowish oil; silica gel $60 \mathrm{~F}_{254}$, petroleum ether/ethyl acetate (20:80). $\lambda_{\max } / \mathrm{nm} 267.9,319.0 ;{ }^{1} \mathrm{H}$ NMR $\left(400 \mathrm{MHz}, \mathrm{CDCl}_{3}\right) \delta 7.40(\mathrm{~d}, 1 \mathrm{H}, J 8.4 \mathrm{~Hz}, \mathrm{H}-6$ ') 7.00 (dd, $1 \mathrm{H}, J 8.0,1.6 \mathrm{~Hz}, \mathrm{H}-6), 6.92(\mathrm{~d}, 1 \mathrm{H}, J 1.6 \mathrm{~Hz}, \mathrm{H}-2), 6.72(\mathrm{~d}$, $1 \mathrm{H}, J 8.0 \mathrm{~Hz}, \mathrm{H}-5$ ), 6.57 (d, 1H, J 10.0 Hz, H-4"), 6.54 (d, 1H, J 8.4 Hz, H-5'), 6.24 (s, 1H, H-8), 5.94 (s, 2H, H-2'”'), 5.66 (d, $1 \mathrm{H}, J 10.0 \mathrm{~Hz}, \mathrm{H}-3$ "), 3.85 (s, 3H, R-OCH $\left.\underline{H}_{3}\right), 3.80$ (s, 3H, Ar-OCH $\left.\underline{3}_{3}\right), 1.42$ (s, 6H, H-2"); ${ }^{13} \mathrm{C}$ NMR (100 MHz, $\left.\mathrm{CDCl}_{3}\right) \delta 190.0$ (C-9), 170.2 (C-7), 156.7 (C-4'), 155.4 (C-2'), 148.9 (C-4), 146.9 (C-3), 131.1 (C-6'), 130.3 (C-3'), 129.0 (C-1), 127.2 (C-1'), 123.7 (C-6), 116.6 (C-4”), 114.5 (C-3'), 112.4 (C-5'), 109.6 (C-5), 107.6 (C-2), 101.9 (C-8), 101.2 (C-2"'), 77.6 (C-2"), $63.3\left(\mathrm{Ar}-\mathrm{OCH}_{3}\right), 56.4\left(\mathrm{R}-\mathrm{OCH}_{3}\right)$, $27.9\left(2\right.$ "- $\left.\mathrm{CH}_{3}\right)$; HRMS (pESI) calcd. for $\mathrm{C}_{23} \mathrm{H}_{22} \mathrm{O}_{6}[\mathrm{M}+\mathrm{Na}]^{+}$: 417.1314; found: 417.1319 .

\section{Filipone B (2)}

Viscous yellowish oil; $[\alpha]_{\mathrm{D}}^{25}-9.04\left(c 0.36, \mathrm{CHCl}_{3}\right)$. $\lambda_{\max } / \mathrm{nm} 238.6,348.9 ;{ }^{1} \mathrm{H} \mathrm{NMR}\left(400 \mathrm{MHz}, \mathrm{CDCl}_{3}\right) \delta 13.16$ (s, $1 \mathrm{H}, \mathrm{OH}), 7.95(\mathrm{~m}, 2 \mathrm{H}, \mathrm{H}-2$ and $\mathrm{H}-6), 7.58(\mathrm{~d}, 1 \mathrm{H}, 2.0 \mathrm{~Hz}$, H-2"), 7.56 (sl, 1H, H-6'), 7.53 (dt, 1H, J 7.2, 2.0 Hz, H-4), 7.42 (m, 2H, H-3 and H-5), 6.97 (d, 1H, J 2.0 Hz, H-3"), 6.20 (dd, 1H, J 17.6, $10.8 \mathrm{~Hz}, \mathrm{H}-2$ "'), 5.54 (s, 1H, H-8), 5.33 (tq, 1H, J 7.2, $1.3 \mathrm{~Hz}, \mathrm{H}-2$ '"') $), 5.03$ (dd, 1H, J 17.6, $0.8 \mathrm{~Hz}, \mathrm{H}-3 \mathrm{a}$ "'), 4.98 (dd, 1H, J 10.8, $0.8 \mathrm{~Hz}, \mathrm{H}-3 \mathrm{~b}$ "'), 3.50 (d, 2H, J 7.6 Hz, H-1"'”), 1.79 (sl, 3H, 5"'”- $\underline{\mathrm{C}}_{3}$ ), 1.73 (sl, 3H, 4"'”- $\left.-\underline{\mathrm{H}}_{3}\right), 1.33$ (sl, 3H, 1'"'- $\left.\mathrm{C}_{3}\right), 1.31$ (sl, $3 \mathrm{H}, 1$ '” $\left.-\mathrm{CH}_{3}\right)$; ${ }^{13} \mathrm{C}$ NMR $\left(100 \mathrm{MHz}, \mathrm{CDCl}_{3}\right) \delta 199.8(\mathrm{C}-9)$, 
194.0 (C-7), 158.5 (C-2'), 158.5 (C-4'), 144.4 (C-2”), 137.9 (C-1), 134.1 (3"'”), 133.2 (C-4), 145.8 (C-2"'), 128.7 (C-6), 128.7 (C-2), 128.4 (C-3), 128.4 (C-5), 125.6 (C-6'), 120.9 (2'”'), 117.5 (C-5'), 117.5 (C-3'), 114.6 (C-1'), 112.0 (C-3a"”), 112.0 (C-3b"'), 105.3 (C-3"), 62.1 (C-8), 41.5 (C-1"'), 27.3 (C-1"'”), 26.3 (1'”- $\left.\underline{\mathrm{CH}}_{3}\right), 26.0\left(1^{\prime \prime}{ }^{\prime}-\mathrm{CH}_{3}\right)$, $25.7\left(5\right.$ '"' $\left.-\mathrm{CH}_{3}\right), 17.8\left(4\right.$ '”' $\left.-\mathrm{CH}_{3}\right)$; HRMS (pESI) calcd. for $\mathrm{C}_{27} \mathrm{H}_{28} \mathrm{O}_{4}[\mathrm{M}+\mathrm{Na}]^{+}$: 439.1886; found: 439.1887 .

\section{Filipone C (3)}

Amorphous yellowish powder; $[\alpha]_{\mathrm{D}}^{25}-4.82(c 0.43$, $\left.\mathrm{CHCl}_{3}\right) . \lambda_{\max } / \mathrm{nm} 240.6,387.0 ;{ }^{1} \mathrm{H} \mathrm{NMR}\left(400 \mathrm{MHz}, \mathrm{CDCl}_{3}\right)$ $\delta 8.01$ (m, 2H, H-2 and H-6), 7.58 (d, 1H, J 2.2 Hz, H-2"), 7.50 (tt, $1 \mathrm{H}, J 7.3,1.2 \mathrm{~Hz}, \mathrm{H}-4), 7.40$ (m, 2H, H-3 and H-5), 7.40 (m, 1H, H-6'), 7.18 (dd, 1H, J 8.6, 0.9 Hz, H-5'), 6.91 (dd, 1H, $J$ 2.2, 0.9 Hz, H-3"), 6.09 (dd, 1H, $J$ 17.4, $10.7 \mathrm{~Hz}, \mathrm{H}-2$ '”), 5.87 (s, 1H, H-8), 5.31 (tq, 1H, J 7.0, $1.3 \mathrm{~Hz}, \mathrm{H}-2$ '"') $), 4.91$ (dd, 1H, J 17.4, $1.1 \mathrm{~Hz}, \mathrm{H}-3 \mathrm{a}$ "'), 4.83 (dd, 1H, J 10.7, $1.1 \mathrm{~Hz}, \mathrm{H}-3 \mathrm{~b}$ "'), 4.74 (m, 1H, H-1a"”'), 4.65 (m, 1H, H-1b"'”), 1.64 (s, 3H, 4"'”-C $\underline{H}_{3}$ ), 1.49 (s, 3H, 4"'”- $\left.\mathrm{CH}_{3}\right), 1.19$ (s, 6H, 1'"' - $\left.\underline{\mathrm{H}}_{3}\right)$; ${ }^{13} \mathrm{C}$ NMR (100 MHz, $\left.\mathrm{CDCl}_{3}\right) \delta 197.9$ (C-9), 195.8 (C-7), 158.4 (C-4'), 151.3 (C-2'), 145.8 (C-2"”), 144.7 (C-2"), 139.3 (C-3"”'), 138.7 (C-1), 132.5 (C-4), 128.8 (C-6), 128.8 (C-2), 128.3 (C-1'), 128.2 (C-5), 128.2 (C-3), 126.7 (C-6'), 119.1 (C-2'”'), 118.7 (C-3'), 111.4 (C-3'”), 106.8 (C-5'), 105.5 (C-3"), 70.4 (C-1"”'), 66.5 (C-8), 41.5 (C-1"”), $26.1\left(1^{\prime \prime} "-\mathrm{CH}_{3}\right)$, $25.6\left(5\right.$ "', $\left.-\mathrm{CH}_{3}\right), 17.8\left(4\right.$ "', $\left.-\mathrm{CH}_{3}\right)$; HRMS (pESI) calcd. for $\mathrm{C}_{27} \mathrm{H}_{28} \mathrm{O}_{4}[\mathrm{M}+\mathrm{Na}]^{+}$: 439.1886; found: 439.1915 .

2'-Methoxy-furano-(2", 3", 4', 3')-dibenzoylmethane (4)

Viscous yellowish oil; $[\alpha]^{20}{ }_{\mathrm{D}}+28.31\left(c 0.84, \mathrm{CH}_{2} \mathrm{Cl}_{2}\right)$. Spectroscopic data matched well with literature. ${ }^{6}$

2'-Hydroxy-8-( $\alpha, \alpha$-dimethylallyl)-2",2"-dimethylpyrano(5",6":3',4')-dibenzoylmethane (5)

Yellow needles; $[\alpha]^{25}-8.68(c \quad 0.80, \mathrm{MeOH})$. Spectroscopic data identical to the literature. ${ }^{13}$

\section{Isolonchocarpin (6)}

Yellow needles. ${ }^{1} \mathrm{H}$ and ${ }^{13} \mathrm{C}$ NMR data were coincident with the literature data. ${ }^{17}$

\section{3',4'-Methylenedioxy-furano-(2",3":7,8)-flavone (7)}

Colorless crystals. Spectroscopic data were compared with the literature data. ${ }^{5}$

\section{Antiproliferative activity}

The pure compounds were evaluated for in vitro cytotoxic activities against human tumor cell lines MCF-7 (breast), NCI-H460 (lung), UACC-62 (melanoma), PC-3 (prostate), HT-29 (colon), K562 (leukaemia), OVCAR-3 (ovarian) and NCI-ADR/RES (ovarian expressing phenotype multiple drugs resistance) were provided by National Cancer Institute (NCI). Stock cultures were grown in medium containing $5 \mathrm{~mL}$ RPMI 1640 (GIBCO BRL) supplemented with 5\% fetal bovine serum. Gentamicine

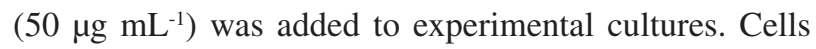
in 96 well plates $\left(100 \mu \mathrm{L}\right.$ cells well $\left.{ }^{-1}\right)$ were exposed to sample concentrations in DMSO/RPMI $(0.25,2.5,25$ and $250 \mu \mathrm{g} \mathrm{mL}-1$ ) at $37{ }^{\circ} \mathrm{C}, 5 \%$ of $\mathrm{CO}_{2}$ in air for $48 \mathrm{~h}$. Doxorubicin was used as positive control. After $48 \mathrm{~h}$ of treatment, cells were fixed with $50 \%$ trichloroacetic acid and cell proliferation determined by spectrophotometric quantification $(540 \mathrm{~nm})$ of cellular protein content using sulforhodamine B assay and total growth inhibition (TGI) was extracted from concentration-response curves. The concentration-response curve was determined through non-linear regression analysis using Origin 8.0 (OriginLab Corporation) software. ${ }^{18,19}$

\section{Results and Discussion}

Previous studies identified one flavone and three dibenzoylmethane derivatives from $L$. filipes (M. filipes). ${ }^{1} \mathrm{In}$ the present study, the dichloromethane extract of $M$. filipes root bark was fractionated and purified by a combination of chromatographic analyses (CC, TLC and preparative TLC). We describe the isolation and identification of one dibenzoylmethane derivative (1), four dibenzoylmethane derivatives with $\alpha, \alpha$-dimethylallyl (prenyl) substituent attached to the central carbon (C-8) (2-5), one flavanone (6), and one flavone (7) (Figure 1).

Compound $\mathbf{1}$ was obtained as a viscous yellowish oil. The ${ }^{1} \mathrm{H}$ NMR spectrum showed the characteristic signals for a 2,2-dimethylchromene moiety at $\delta 1.42(\mathrm{~s}, 6 \mathrm{H}$, 2"'- $\left.\mathrm{CH}_{3}\right), 5.66(\mathrm{~d}, 1 \mathrm{H}, J 10.0 \mathrm{~Hz}, \mathrm{H}-3$ ") and 6.57 (dd, $1 \mathrm{H}$, $J$ 10.0, $0.5 \mathrm{~Hz}, \mathrm{H}-4$ "'). This was confirmed in the ${ }^{13} \mathrm{C}$ NMR spectrum by the signals at $\delta 27.9\left(2\right.$ "'- $\left.\mathrm{CH}_{3}\right), 77.6(\mathrm{C}-2$ "), 130.3 (C-3") and 116.6 (C-4"). The 2,2-dimethylchromene group located at ring $\mathrm{B}$ in the angular position, i.e., linked in C-3'/C-4', was confirmed in the ${ }^{1} \mathrm{H}$ NMR spectrum by the signals of two ortho coupled hydrogens at $\delta 6.54(\mathrm{dd}, 1 \mathrm{H}$, $J$ 8.4, $0.8 \mathrm{~Hz}, \mathrm{H}-5^{\prime}$ ) and 7.40 (d, 1H, $\left.J 8.4 \mathrm{~Hz}, \mathrm{H}-6^{\prime}\right)$. The methylenedioxy group was shown in the ${ }^{1} \mathrm{H}$ NMR spectrum by the signal at $\delta 5.94$ (2H, s, H-2"'). The position of this group in ring A was confirmed by the signals of one ortho coupled aromatic hydrogens at $\delta 6.72(\mathrm{~d}, 1 \mathrm{H}, J 8.0 \mathrm{~Hz}$, $\mathrm{H}-5$ ), one coupled ortho and meta at $\delta 7.00(\mathrm{dd}, 1 \mathrm{H}, J 8.0$, $1.6 \mathrm{~Hz}, \mathrm{H}-6)$ and one coupled meta at $\delta 6.92(\mathrm{dd}, 1 \mathrm{H}$, $J 1.6 \mathrm{~Hz}, \mathrm{H}-2$ ). The signal of carbonyl groups at $\delta 190.0$ 
<smiles>CO/C(=C/C(=O)c1ccc2c(c1OC)C=CC(C)(C)O2)c1ccc2c(c1)OC[CH]2</smiles><smiles>C=CC(C)(C)C(C(=O)c1ccccc1)C(=O)c1ccc2occc2c1OC</smiles>

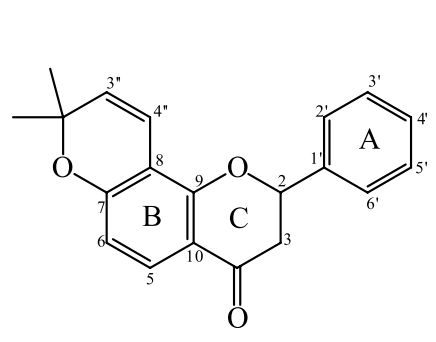

6<smiles></smiles>

2<smiles>C=CC(C)(C)C(C(=O)c1ccccc1)C(=O)c1ccc2occc2c1OCC=C(C)C</smiles>

3<smiles>C=CC(C)(C)C(C(=O)c1ccccc1)C(=O)c1ccc2c(c1O)C=CC(C)(C)O2</smiles><smiles>O=c1cc(-c2ccc3c(c2)OCO3)oc2c1ccc1occc12</smiles>

7

Figure 1. Flavonoids isolated from root bark of Muellera filipes (Benth) M.J. Silva \& A.M.G. Azevedo.

(C-9) and 170.2 (C-7) in the ${ }^{13} \mathrm{C}$ NMR were in accordance with a non-enolizable dibenzoylmethane skeleton..$^{20,21}$ In the heteronuclear multiple bond correlation (HMBC) experiment (Figure 2), the correlations of the hydrogen signals at $\delta 3.85\left(7-\mathrm{OCH}_{3}\right)$ with the carbon at $\delta 170.2$ $(\mathrm{C}-7)$, and of $\delta 3.80\left(2^{\prime}-\mathrm{OCH}_{3}\right)$ with $\delta 155.4\left(\mathrm{C}-2^{\prime}\right)$ were in agreement with the presence of a $\beta$-methoxyl group $\left(7-\mathrm{OCH}_{3}\right)$ and a methoxyl group bonded to the benzene ring $\left(2 '-\mathrm{OCH}_{3}\right)$, respectively. The location of a $\beta$-methoxyl group at $\mathrm{C}-7$ was further confirmed by correlations of the hydrogen signal at $\delta 6.24(\mathrm{H}-8)$ with the carbon at $\delta 170.2$ (C-7). The stereochemistry $E$ of double bond (C-7/C-8) was proposed based on the study carried out with the isomers of $\beta$-methoxychalcones. ${ }^{22}$ The correlations of the hydrogen signal at $\delta 7.40$ (H-6') with 190.0 (C-9) and 155.4 (C-2') showed that the carbonyl and methoxyl groups are bonded to the tetrasubstituted ring $\mathrm{B}$ of $\beta$-methoxychalcone.

On the basis of this spectroscopic evidence, the structure of the new compound $\mathbf{1}$ (Figure 1) was established as (E)-3,4-methylenedioxy-2'methoxy-2", 2"-dimethylpyrano$(5 ", 6 ": 3 ', 4 ')-7$ methoxychalcone, named filipone A.

Compound $\mathbf{2}$ was also isolated as a viscous yellowish oil. In the ${ }^{1} \mathrm{H}$ NMR spectrum, signals for a monosubstituted aromatic ring $[\delta 7.95(\mathrm{~m}, 2 \mathrm{H}, \mathrm{H}-2, \mathrm{H}-6), 7.53(\mathrm{dt}, 1 \mathrm{H}$, $J$ 7.2, $2.0 \mathrm{~Hz}, \mathrm{H}-4)$ and $7.42(\mathrm{~m}, 2 \mathrm{H}, \mathrm{H}-3, \mathrm{H}-5)$ ]; one $\alpha, \alpha$-dimethylallyl group $[\delta 6.20(\mathrm{dd}, 1 \mathrm{H}, J 17.6,10.8 \mathrm{~Hz}$, H-2"'), 4.98 (d, 1H, J 10.8, 0.8 Hz, H-3b"”), 5.03 (dd, 1H, $J$ 17.6, $0.8 \mathrm{~Hz}, \mathrm{H}-3 \mathrm{a}$ "'), 1.31 (s, 3H) and 1.33 (s, 3H)]; one uncoupled methynic hydrogen $[\delta 5.54(\mathrm{~s}, 1 \mathrm{H}, \mathrm{H}-8)]$; one furan ring $[\delta 6.97(\mathrm{~d}, 1 \mathrm{H}, J 2.0 \mathrm{~Hz}, \mathrm{H}-3$ ") $)$ and 7.58 (d, 1H, J $2.0 \mathrm{~Hz}, \mathrm{H}-2$ ")]; and one hydrogen bonded by hydroxy group $[\delta 13.16$ (s, $1 \mathrm{H}, 2$ '-OH)] were observed. The isoprenyl group was confirmed in the ${ }^{1} \mathrm{H}$ NMR spectrum by the signals at $\delta 3.50$ (d, $2 \mathrm{H}, J 7.6 \mathrm{~Hz}, \mathrm{H}-1$ '"' '), 5.33 (ts, $1 \mathrm{H}, J$ 7.2, $1.6 \mathrm{~Hz}, \mathrm{H}-2$ '"'”), 1.73 (s, 3H, 4"'”- $\mathrm{CH}_{3}$ ), and $1.79\left(\mathrm{~s}, 3 \mathrm{H}, 5\right.$ "'” $\left.-\mathrm{CH}_{3}\right)$. The signals of two carbonyl groups $\left(\delta 199.8\right.$ and 194.0) in the ${ }^{13} \mathrm{C}$ NMR were in accordance with a non-enolizable dibenzoylmethane skeleton. ${ }^{6}$ The ${ }^{13} \mathrm{C}$ NMR spectrum and DEPT $135^{\circ}$ indicated the presence of 10 quaternary carbons, $11 \mathrm{CH}, 2 \mathrm{CH}_{2}$ and $4 \mathrm{CH}_{3}$. In the HMBC experiment (Figure 2), the correlations of the hydrogen signals at $\delta 7.95(\mathrm{H}-2$ and $\mathrm{H}-6)$ with the carbon at $\delta 194.0$, and $\delta 7.56(\mathrm{H}-6$ ') with the carbon at $\delta 199.8$ confirmed the position of the carbonyl groups in C-7 and C-9, respectively. The hydrogen signal at $\delta 3.50$ (H-1"'"') showed correlations with the carbons at $\delta 117.5$ (C-5'), 


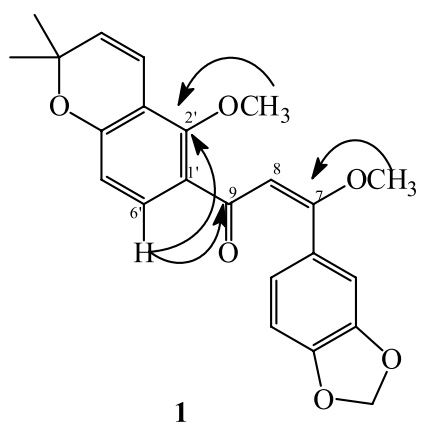

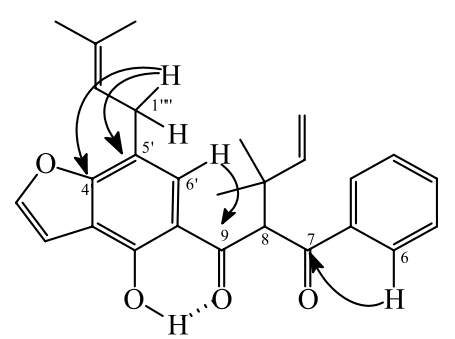

2

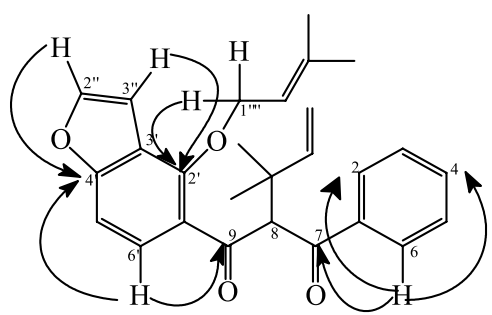

3

Figure 2. Key correlations of compounds 1-3, determined from the HMBC experiment.

125.6 (C-6') and 158.7 (C-4') suggesting the presence of the isoprenyl group in the B ring benzoyl moiety. These data suggest two structural possibilities concerning the alternative isoprenyl group, located in C-3' or C-5' of the $B$ ring. In the NOE (nuclear Overhauser effect) difference experiment (Figure 3), irradiation of the isoprenyl group hydrogens at $\mathrm{H}-1$ '"' $(\delta 3.50)$ enhanced the signals at H-6' $(\delta$ 7.56) and H-5"'" $(\delta$ 1.74), while irradiation of one aromatic hydrogen at $\mathrm{H}-6$ ' $(\delta$ 7.56) further enhanced the same isoprenyl group signal at H-1"', $(\delta 3.50)$ and H-8 $(\delta$ 5.54). Irradiation of the furan ring hydrogen at $\mathrm{H}-3$ " $(\delta$ 6.97) enhanced the signal at H-2" $(\delta$ 7.58). These findings are in agreement with structure 2 (Figure 3).

The MS spectrum showed the base peak at $m / z 105$ and a peak at $m / z 229$, which can be interpreted respectively as the C-7/C-8 and C-9/C-8 bond cleavage of a dibenzoylmethane, confirming the location of the $\alpha, \alpha$-dimethylallyl group on $\mathrm{C}-8$. The presence of $\alpha, \alpha$-dimethylallyl was further confirmed by a peak at $\mathrm{m} / \mathrm{z} 279$ (Scheme 1). Therefore, the new compound $\mathbf{2}$ was determined as 2'-hydroxy5 '-(3'"', ,3'"'-dimethylallyl)-8-( $\alpha, \alpha^{\prime}$-dimethylallyl)-furano[4", 5":3',4']-dibenzoylmethane, named filipone B.

Compound $\mathbf{3}$ was isolated as a yellow amorphous solid. Its ${ }^{1} \mathrm{H}$ and ${ }^{13} \mathrm{C}$ NMR spectra showed close similarities to compound $\mathbf{2}$, in the presence of one $\alpha, \alpha$-dimethylallyl group, one furan ring and two carbonyl groups, shown in the ${ }^{13} \mathrm{C}$ NMR spectrum by the signals at $\delta 195.8$ (C-7) and 197.9 (C-9). However, compound $\mathbf{3}$ has an $O$-prenyl group on the

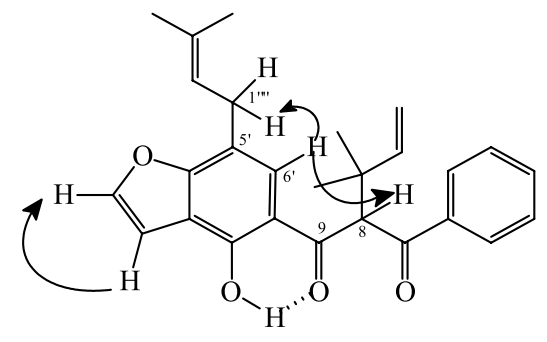

2
B ring, shown in the ${ }^{1} \mathrm{H}$ NMR spectrum by the signals at $\delta 4.74$ (m, 1H, H-1"'”'), 4.65 (m, 1H, H-1 "'”), 5.31 (tq, 1H, $J$ 7.0, 1.3, H-2'"''), 1.49 (s, 3H, 4'"' $-\mathrm{CH}_{3}$ ) and 1.64 (s, 3H, 5 "' '- $\mathrm{CH}_{3}$ ). This was confirmed in the ${ }^{13} \mathrm{C}$ NMR spectrum by the signals at $\delta 70.4$ (C-1"'”), 119.1 (C-2"'”), 139.3 (C-3"”'), 17.9 (C-4"'") and 25.6 (C-5"'”), respectively. In the HMBC experiment (Figure 2), the correlations of the hydrogen signals at $\delta 7.58$ (H-2") with the carbon at $\delta 158.4$ (C-4'), $\delta 6.91$ (H-3") with the carbon at $\delta 118.7$ (C-3'), 4.74 (H-1a"'”), and 4.65 (H-1b"'") with the carbon at $\delta 151.3$ (C-2'), and of the signal at $\delta 7.40$ (H-6') with the carbons at $\delta 151.3$ (C-2'), 158.4 (C-4'), and 197.9 (C-9) were in agreement with the tetrasubstituted ring $\mathrm{B}$, while the signal at $\delta 1.19\left(1\right.$ '"' $\left.-\mathrm{CH}_{3}\right)$ with the carbon at $\delta 66.5$ (C-8) confirmed the $\alpha, \alpha$-dimethylallyl group connected at C-8. The correlation of the hydrogen signal at $\delta 8.01$ (H-6) with carbons at $\delta 128.8(\mathrm{C}-2), 132.5(\mathrm{C}-4)$, and 195.8 (C-7) confirmed the presence of a monosubstituted ring A. These data suggest two possible isomers for structure 3 . In the NOE difference experiment (Figure 3), irradiation of the $O$-prenyl group hydrogens at $\delta 4.74$ (H-1"'"'a) and 4.65 (H-1"'”b) further enhanced the signal of furan ring hydrogen at $\delta 6.91$ (H-3") and methinic hydrogen of an $\alpha, \alpha$-dimethylallyl group at $\delta 1.19\left(1\right.$ '"'- $\left.\underline{\mathrm{H}}_{3}\right)$, suggesting that the furan ring was connected at an angle to the $\mathrm{B}$ ring, with the $O$-prenyl group adjacent to the furan ring and located at carbon C-2'. In the MS spectrum, the fragmentation pathway is analogous to that of $\mathbf{2}$ (Scheme 1).

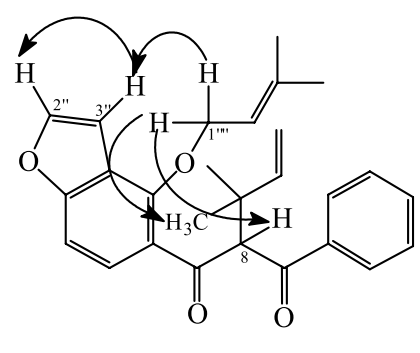

3

Figure 3. NOE effects observed for compounds $\mathbf{2}$ and $\mathbf{3}$. 


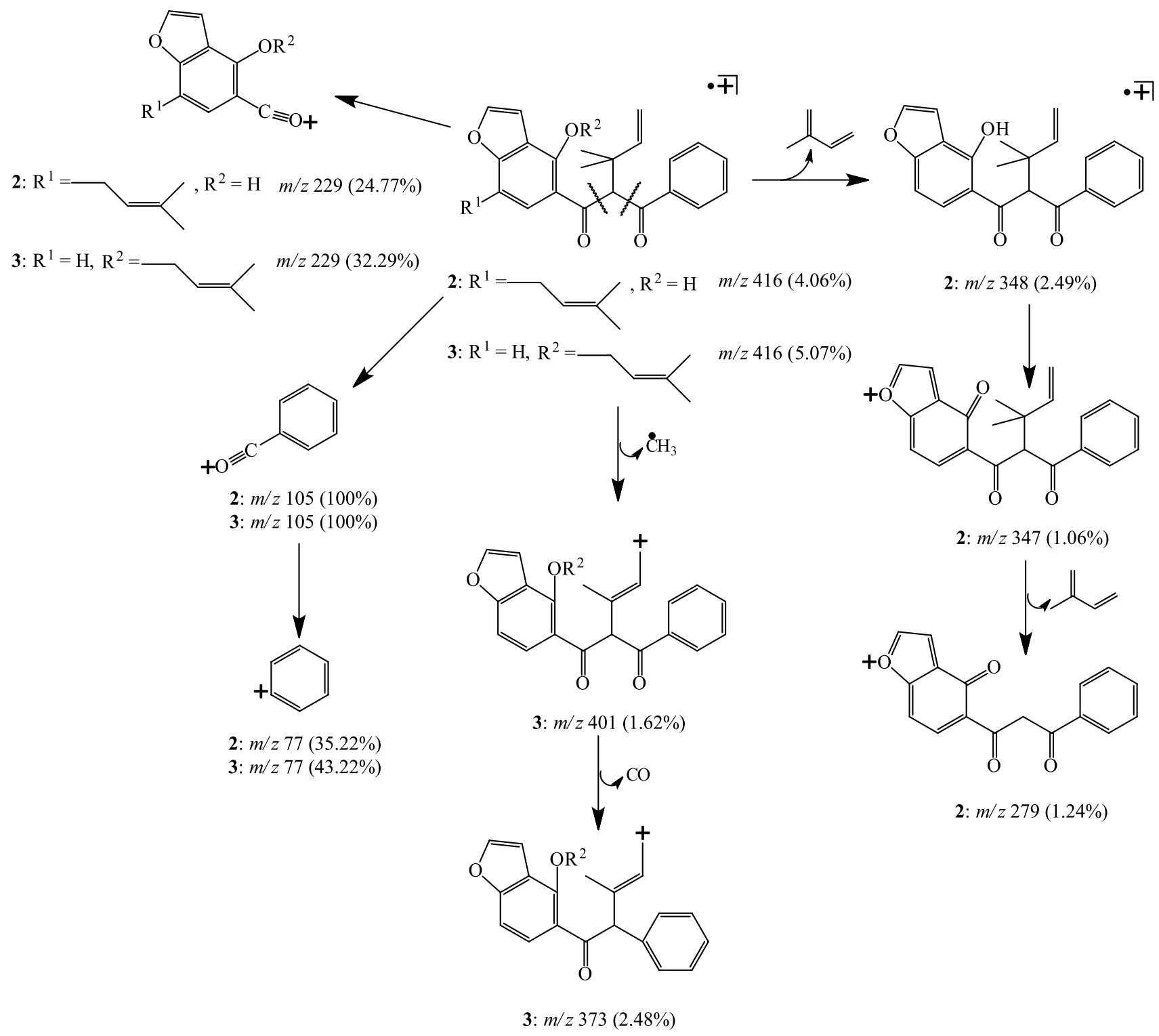

Scheme 1. Proposed fragmentation mechanisms of $\mathbf{2}$ and $\mathbf{3}$ (only peaks classified as principals).

On the basis of the above evidence, the structure of the new compound $\mathbf{3}$ was established as 2'-O-(3"', ,3"',dimethylallyl)-8-( $\alpha, \alpha$-dimethylallyl)-furano-(4", $\left.5^{\prime \prime}: 3^{\prime}, 4^{\prime}\right)$ dibenzoylmethane, named filipone $\mathrm{C}$.

The known compounds (4-7) were characterized by comparison of the respective spectral data with those found in the literature. ${ }^{5,6,13,17}$

Dibenzoylmethanes can coexist with their equivalent with an $\alpha, \alpha$-dimethylallyl (prenyl) group affixed to the central carbon (C-8). Dibenzoylmethane derivatives (2, 3, 4 and 5) with a substituent on C-8 are extremely rare in nature. They have been found only in the three closely related genera, Lonchocarpus, Dahlstedtia and Muellera, mainly in species from Brazil such as D. muehlbergiana, ${ }^{10}$ D. glaziovii, ${ }^{11} M$. montana, ${ }^{13}$ and $M$. filipes, ${ }^{1}$ except for
L. latifolius which occurs in Venezuela, Bolivia and Mexico, ${ }^{8}$ and M. fluvialis which occurs in Argentina, Paraguay and Bolivia. ${ }^{12}$ The abundance of these compounds in M. filipes reinforces its allocation together with Muellera montana in the new classification of the genera Lonchocarpus, Dahlstedtia and Muellera. ${ }^{2}$ The structures of the most abundant dibenzoylmethanes ( 3 and $\mathbf{4}$ ) furnished by $M$. filipes are biosynthetically related. ${ }^{13,23,24}$ The presence of compounds considered biomarkers in a small group of closely related genera can support inferences about biogenetic and evolutionary aspects, based on the metabolic pathways that govern the synthesis of these compounds. ${ }^{5,25}$

Dibenzoylmethane derivatives $\mathbf{3}$ and $\mathbf{4}$ were assayed for cytotoxicity, using eight human cancer cell lines: MCF-7 (breast), NCI-H460 (lung), UACC-62 (melanoma), PC-3 
Table 1. Total growth inhibition (TGI) ( $\mu \mathrm{M})$ of dibenzoylmethane derivatives $\mathbf{3}$ and $\mathbf{4}$ against human cancer cells

\begin{tabular}{lcccccccccc}
\hline \multirow{2}{*}{ Compound } & \multicolumn{8}{c}{ Cell lines } \\
\cline { 2 - 9 } & UACC-62 & MCF7 & NCI-ADR/RES & NCI-H460 & PC-3 & OVCAR-3 & HT-29 & K562 & VERO \\
\hline $\mathbf{3}$ & $>600$ & $>600$ & $>600$ & $>600$ & $>600$ & 52.35 & $>600$ & $>600$ & $>600$ \\
$\mathbf{4}$ & 91.67 & $>600$ & 85.43 & 6.46 & $>600$ & 125.96 & $>600$ & 32.80 & $>600$ & \\
Doxorubicin $^{\mathrm{a}}$ & 0.33 & 1.84 & $>45$ & 1.42 & 2.30 & 8.11 & $>45$ & 0.55 & $>45$ \\
\hline
\end{tabular}

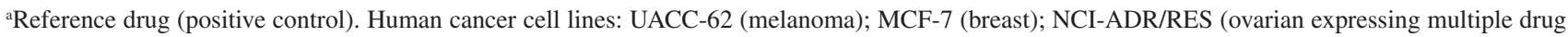
resistant phenotype); NCI-H460 (lung); PC-3 (prostate); OVCAR-3 (ovarian); HT-29 (colon); K-562 (leukemia); VERO (renal, normal cells, green monkey).

(prostate), HT-29 (colon), K-562 (leukemia), OVCAR-3 (ovarian) and NCI-ADR/RES (ovarian expressing a multiple drug resistant phenotype). The inhibitory effects of compounds $\mathbf{3}$ and $\mathbf{4}$ were assessed by varying the concentrations $(0.60$ to $600 \mu \mathrm{M})$ and the results were obtained after $48 \mathrm{~h}$ using the sulforhodamine B method. All assays were performed in triplicate, and the results were expressed as the concentration-dependent parameter TGI (concentration that produces total growth inhibition or cytostatic effect) (Table 1).

Compound 3 was selective for the OVCAR-3 (ovarian) cell line, but less selective than the positive control (doxorubicin), based on the TGI values (Table 1). On the other hand, compound $\mathbf{4}$ showed strong activity against the NCI-H460 (lung) cell line (TGI $=6.46 \mu \mathrm{M}$ ) and was selective for the K-562 (leukemia), OVCAR-3 (ovarian), NCI-ADR/RES (ovarian expressing a multiple drug resistant phenotype) and UACC-62 (melanoma) cell lines compared to the positive control (doxorubicin). This therapeutic activity against melanoma cells is particularly interesting for antimelanoma studies, because dibenzoylmethane derivatives can protect against UVA/UVB radiation, which plays a significant role in sunlight-induced skin damage. ${ }^{15,26}$ Compounds 1-2 and 5-7 were not tested for antiproliferative activity due to the small amount of each sample available.

\section{Conclusions}

Scrutiny of the structural variations may enable chemotaxonomic proposals to be drawn; thus dibenzoylmethane derivatives with a substituent on C-8 characterize some species of the genera Lonchocarpus, Dahlstedtia and Muellera of the family Fabaceae. The occurrence of these compounds in Muellera filipes reinforces its allocation together with Muellera montana in the new classification of these three closely related genera, based on the phylogenetic and morphological analyses. Compounds $\mathbf{3}$ and $\mathbf{4}$ showed high selectivity against human tumor cell lines, and compound $\mathbf{4}$ is a candidate for further study as a sunscreen against UVA/UVB radiation.

\section{Supplementary Information}

1D and 2D NMR spectra and HRMS data for compounds 1-3 are available free of charge at http://jbcs. sbq.org.br as PDF file.

\section{Acknowledgments}

The authors are grateful to Conselho Nacional de Desenvolvimento Científico e Tecnológico (CNPq) for a scholarship and financial support.

\section{References}

1. Santos, E. L.; Costa, E. V.; Marques, F. A.; Vaz, N. P.; Magalhães, E. G.; Tozzi, A. M. A.; Maia, B. H. L. N. S.; Quim. Nova 2009, 9, 2255.

2. da Silva, M. J.; Queiroz, L. P.; Azevedo-Tozzi, A. M. G.; Lewis, G. P.; Sousa A. P.; Taxon 2012, 61, 93.

3. da Silva, M. J.; Azevedo-Tozzi, A. M. G.; Phytotaxa 2011, 29, 41.

4. Cassidy, C. E.; Setzer, W. N.; Nat. Prod. J. 2011, 1, 75.

5. Garcez, F. R.; Scramin, S.; do Nascimento, M. C.; Mors, W. B.; Phytochemistry 1988, 27, 1079.

6. Magalhães, A. F.; Tozzi, A. M. G. A.; Magalhães, E. G.; Blanco, I. S.; Nogueira, M. A.; Phytochemistry 1997, 46, 1029.

7. Waterman, P. G.; Mahmoud, E. N.; Phytochemistry 1985, 24, 571.

8. Magalhães, A. F.; Tozzi, A. M. A.; Magalhães, E. G.; Nogueira, M. A.; Queiroz, S. C. N.; Phytochemistry 2000, 55, 787.

9. Magalhães, A. F.; Azevedo-Tozzi, A. M. G.; Maia, B. H. L. N. S.; Magalhães, E. G.; Phytochemistry 1996, 42, 1459.

10. Magalhães, A. F.; Tozzi, A. M. G. A.; Magalhães, E. G.; Blanco, I. S.; Soriano, M. P. C.; An. Acad. Bras. Cienc. 2004, 76, 651.

11. Canzi, E. F.; Marques, F. A.; Teixeira, S. D.; Tozzi, A. M. G. A.; Silva, M. J.; Duarte, R. M. T.; Ruiz, A. L. T. G.; Monteiro, P. A.; Carvalho, J. E.; Maia, B. H. L. N. S.; J. Braz. Chem. Soc. 2014, 6, 995.

12. Blatt, C. T. T.; Chávez, D.; Chai, H.; Graham, J. G.; Cabieses, F.; Farnsworth, N. R.; Cordell, G. A.; Pezzuto, J. M.; Kinghorn, A. D.; Phytother. Res. 2002, 16, 320. 
13. Magalhães, A. F.; Tozzi, A. M. G. A.; Magalhães, E. G.; Sannomiya, M.; Soriano, M. P. C.; Perez, M.; An. Acad. Bras. Cienc. 2007, 79, 351.

14. Nogueira, M. A.; Magalhães, E. G.; Magalhães, A. F.; Biloti, D. N.; Laverde, A.; Pessine, F. B.; Carvalho, J. E.; Kohn, L. K.; Antônio, M. A.; Marsaioli, A. J.; Il Farmaco 2003, 58, 1163.

15. Atarashi, K.; Takano, M.; Kato, S.; Kuma, H.; Nakanishi, M.; Nakanishi, M.; Tokura, T.; J. Photochem. Photobiol. B 2012, 113,56 .

16. Santos, D. A. P.; Braga, P. A. C.; Silva, M. F. G. F.; Fernandes, J. B.; Vieira, P. C.; Magalhães, A. F.; Magalhães, E. G.; Marsaioli, A. J.; Moraes, V. R. S.; Rattray, L.; Croft, S. L.; J. Pharm. Pharmacol. 2009, 61, 257.

17. Rao, E. V.; Raju, N. R.; Phytochemistry 1979, 18, 1581.

18. Shoemaker, R. H.; Nat. Rev. Cancer 2006, 6, 813.

19. Spindola, H. M.; Carvalho, J. E.; Ruiz, A. L. T. G.; Rodrigues, R. A. F.; Denny, C.; Sousa, I. M. O.; Tamashiro, J. Y.; Foglio, M. A.; J. Braz. Chem. Soc. 2009, 20, 569.
20. Parmar, V. S.; Rathore, J. S.; Jain, R.; Malone, J. F.; Phytochemistry 1989, 28, 591.

21. Fukai, T.; Nishizaka, J.; Nomura, T.; Phytochemistry 1994, 35, 515.

22. Kiuchi, F.; Chen, X.; Tsuda, Y.; Chem. Pharm. Bull. 1990, 38, 1862.

23. Gottlieb, O. R.; Micromolecular Evolution, Systematic and Ecology - An Essay into a Novel Botanical Discipline, $1^{\text {st }}$ ed.; Springer-Verlag Berlin Heidelberg: Berlin, German, 1982.

24. Chamberlajin, T. R.; Collins, J. F.; Grundon, M. F.; Chem. Commun. 1969, 1269.

25. Wink, M.; Phytochemistry 2003, 64, 3.

26. Simeoni, S.; Scalia, S.; Benson, H. A. E.; Int. J. Pharm. 2004, $280,163$.

Submitted: September 25, 2016

Published online: December 20, 2016 